\title{
КОНСТИТУЦЙНО-ПРАВОВИЙ СТАТУС ІНОЗЕМЦІВ В УКРАЇНІ ТА ДЕЯКІ ОСОБЛИВОСТІ РЕАЛІЗАЦІЇ ЇХНІХ ПРАВ І СВОБОД
}

\begin{abstract}
Анотація. У статті систематизовано та узагальнено сучасні науково-методологічні підходи щодо понять «правовий статус особи» та «конституційно-правовий статус особи», та питання конституційно-правового статусу іноземців в Україні. Визначено сутність і принципи конституційно-правового статусу іноземців в Україні. Здійснено загальну характеристику їхніх прав і свобод. З'ясовано обсяг конституційних обов'язків іноземців, які постійно проживають на територї України. Зауважено, що на території України на законних підставах можуть постійно або тимчасово проживати такі категорії осіб, як іноземні громадяни, особи без громадянства, біженці, особи, які потребують тимчасового або додаткового захисту. Конституційноправовий статус цих осіб базується на загальному правовому статусі людини і визначається Конституцією України та відповідними законодавчими актами. Актуальність питання вдосконалення вітчизняного законодавства щодо обсягу, змісту, механізмів реалізащії та відповідності світовим стандартам основних прав і свобод іноземців є невід'ємною передумовою для розширення співробітництва України із зарубіжними країнами та її прагнення до повноцінного членства в Свропейському Союзі.
\end{abstract}

Ключові слова: громадянство, іноземці, конституційні обов’язки, правовий статус особи, права і свободи іноземців, принципи.

Steblianko Alina, Bezvin Olexiy Sumy State University

\section{CONSTITUTIONAL AND LEGAL STATUS OF FOREIGNERS IN UKRAINE AND SOME FEATURES OF THE EXERCISE OF THEIR RIGHTS AND FREEDOMS}

Summary. The article systematizes and generalizes modern scientific and methodological approaches to the issue of the constitutional and legal status of foreigners in Ukraine. Scientific and methodological approaches to defining the concepts of "legal status of a person" and "constitutional and legal status of a person" are generalized. The essence and principles of the constitutional and legal status of foreigners in Ukraine are determined. The general characteristic of their rights and freedoms is carried out. The scope of constitutional obligations of foreigners permanently residing in Ukraine has been clarified. Such categories of persons as foreign citizens, stateless persons, refugees, persons in need of temporary or additional protection may legally or temporarily reside on the territory of Ukraine. The constitutional and legal status of these persons is based on the general legal status of a person and is determined by the Constitution of Ukraine and relevant legislative acts. The constitutional and legal status of foreign citizens staying in Ukraine on legal grounds is a holistic internally agreed set of their rights, freedoms and responsibilities, as well as the principles of the legal status of foreign citizens, guarantees of their rights and freedoms. The principles of exercising foreigners' rights, freedoms and responsibilities are determined by the legal regime of foreigners. In Ukraine, there is a national regime for foreigners, which provides for equal rights and freedoms of foreign citizens and citizens of Ukraine, with the exceptions (primarily political rights) established by the Constitution, laws and international treaties of Ukraine. Foreigners in Ukraine, along with citizens of Ukraine, have a certain amount of constitutional responsibilities. The urgency of improving domestic legislation on the scope, content, implementation mechanisms and compliance with international standards of fundamental rights and freedoms of foreigners is an integral prerequisite for expanding cooperation between Ukraine and foreign countries and its desire for full membership in the European Union.

Keywords: citizenship, foreigners, constitutional obligations, legal status of a person, rights and freedoms of foreigners, principles.

$\Pi^{2}$ остановка проблеми. Нині Україна перебувае у процесі конституційного-правового реформування та імплементації евроінтеграційного законодавства для досягнення максимального зближення з країнами Європейського Союзу. Слід зазначити, що саме у питанні гармонізації вітчизняного права з европейським і виникае дуже багато проблем, які потребують вирішення. Недоліком нормативного забезпечення основних прав, свобод і обов'язків іноземців в Україні $е$ те, що ці ключові структурні елементи конституційно-правового статусу не отримали свого систематичного закріплення у профільному Законі України «Про правовий статус іноземців та осіб без громадянства», що ускладнюе їх аналіз, реалізацію та захист. Іно- земці, на відміну від громадян України, мають дещо інше коло прав, зокрема, по відношенню до держави. Тому аналіз їх конституційно-правового статусу та деяких особливостей реалізації їхніх прав та свобод $є$ важливим елементом, який потребуе досконалого дослідження.

Аналіз останніх досліджень і публікацій. Відзначимо важливість впливу на формування методології дослідження конституційно-правового статусу іноземців в Україні, його складових елементів серед праць таких учених як А. Грабильніков, А. Левенець, Т. Назаров, Є. Петров, Н. Погорецька, Ю. Тодика та ін.

Виділення невирішених раніше частин загальної проблеми. Аналіз наукових праць за обраною темою свідчить про відсутність еди- 
ного підходу до розуміння понять «іноземець», «правовий статус особи», «конституційно-правовий статус іноземців», та їх змістовного наповнення, що й обумовлюе необхідність і своєчасність їх подальшого вивчення. До того ж, вітчизняним законодавством не в повній мірі регламентовано участь іноземних громадян, які постійно проживають на території України, у політичному та військовому житті країни.

Мета статті. Головною метою ціеї роботи $€$ визначення сутності та змісту конституційно-правового статусу іноземців в Україні через пізнання його структурних елементів, а також визначення особливостей реалізації їхніх прав і свобод у політичній та військовій сфрерах.

Виклад основного матеріалу. У сучасній правничій науці немає єдиного підходу до визначення сутності поняття «правовий статус особи», його структури та класифікації. У загальній теорії права усталеним залишається розуміння правового статусу особи як юридично закріпленого становища особистості у суспільстві. М. Вiтрук пропонуе розрізняти два самостійних поняття - «правовий статус (становище) особи» у широкому значенні та «правовий статус (становище) особи» у вузькому. Умовно, перше поняття можна розглядати як "правове становище», а друге - як «правовий статус» (незважаючи на етимологічну тотожність категорій «становище» і «статус»). Ядром правового становища особи, на думку автора, є система юридичних прав, свобод, обов'язків і законних інтересів особи в їх едності, тобто правовий статус особи. Структурними елементами правового становища особи є громадянство та правосуб'єктність як необхідні умови володіння правовим статусом особи та його юридичні гарантії. Елементом правового становища особи і його структурних складових М. Вітрук називає принципи, закріплені у законі чи такі, що випливають із правової природи відносин особи, суспільства і держави [1, с. 22].

Сутнісною характеристикою правового статусу особи $є$ комплекс іï юридичних прав, свобод та обов'язків. Під поняттям «права та свободи іноземців в Україні» Є. Петров пропонуе розуміти «визначені міжнародними договорами, згода на обов'язковість яких надана Верховною Радою України, Конституцією та законами України можливості іноземців обирати вид і міру своєі поведінки 3 метою користування економічними, соціальними, культурними та іншими благами для задоволення особистих законних інтересів і потреб» [4].

Конституційно-правовий статус іноземців у контексті нашого питання пропонуємо розглядати як цілісний внутрішньо узгоджений комплекс взаємопов'язаних прав, свобод і обов'язків іноземного громадянина, який перебуває в Україні на законних підставах. Ставлення держави до перебування іноземців на її території, загальні принципи регулювання правовідносин, в які вступають іноземці на території держави перебування, визначає режим іноземщів. Він відображає засади здійснення іноземцями своїх прав, свобод і обов'язків.

В Законі України «Про правовий статус іноземців та осіб без громадянства" визначена дефініція поняття «іноземного громадянина», так: «іно- земець - особа, яка не являється у громадянстві України і є громадянином (підданим) іншої держави або держав» [2]. Відповідно до статті 26 частини 1 Конституції України: «Іноземщі та особи без громадянства, що перебувають в Україні на законних підставах, користуються тими самими правами і свободами, а також несуть такі самі обов'язки, як і громадяни України, - за винятками, встановленими Конститущією, законами чи міжнародними договорами України» [3]. Також, іноземці на території України можуть отримати притулок і мають право на набуття громадянства (стаття 8-9 закону «Про правовий статус іноземщів та осіб без громадянства») [2].

Конституційно-правовий статус іноземних громадян в Україні регламентують норми Конституції України, норми міжнародного права, Закони України «Про правовий статус іноземців та осіб без громадянства», "Про біженців та осіб, які потребують додаткового або тимчасового захисту» та інші нормативно-правові акти.

Конституція поширюе національний правовий режим на іноземців, однак він має певні межі. Іноземці в Україні не користуються більшістю політичних прав та обов'язків. Стаття 36 Конституції проголошуе, що громадяни України можуть об'єднуватися у політичні партії та громадські організації [3]. Проте, Закон України «Про громадські об'єднання» надає право іноземцям бути засновниками та членами громадських організащій (частина перша стаття 7 і 8) [5]. Стаття 70 КУ закріплюе право голосу на виборах та редерендумах за громадянами України. Стаття 38 затверджуе виключне право громадян брати участь в управлінні державними справами, у всеукраїнському та місцевих редерендумах, вільно обирати і бути обраними до органів державної влади та органів місцевого самоврядування [3]. Можемо констатувати той фракт, що політичні права і свободи належать людині як члену політичного співтовариства, в якому вона виступає передусім як громадянин України. Особливістю політичних праві і свобод $є$ те, що за винятком права на об'єднання у неполітичні організації та права на індивідуальні чи колективні звернення, вони належать виключно громадянам України.

Ряд науковців підтримують підхід щодо доцільності розширення прав іноземців у політичній сдрері. Так, А. Чернявський пропонуе забезпечити іноземним громадянам та особам без громадянства, які постійно приживають на території України, активного, а по можливості - і пасивного виборчого права під час проведення місцевих виборів та місцевих редерендумів» [6, с. 26].

Необхідно також ураховувати, що у деяких країнах ЄC передбачена можливість участі іноземщів у місцевих виборах. Параграфи 2, 7 Закону Словаччини «Про вибори до органів самоврядування регіонів і доповнення до Цивільного процесуального кодексу» [7], містять вимоги про включення до списку виборців іноземців, які мають постійне місце проживання у відповідному регіоні та досягли вісімнадцятирічного віку.

Конституція Іспанії передбачає, що певними договорами або законом іноземцям на муніципальних виборах може бути надано активне виборче право. 
У Німеччині на виборах в органи місцевого самоврядування іноземці, які постійно проживають на ї̈ території і при цьому не є офіційними представниками міжнародних організацій чи іноземних держав, все частіше отримують право голосу, а іноді й пасивне виборче право [8, с. 758].

Варто підкреслити, що враховуючи положення статті 6 Конвенції про участь іноземців у суспільному житті на місцевому рівні, прийнятої Радою Європи у 1992 рощі, Україна зобов'язуеться надати кожному постійному мешканцю іноземцю право голосувати та висувати свою кандидатуру на виборах до місцевого самоврядування, якщо він задовольняе тим правовим вимогам, які ставляться перед громадянами i, крім того, на законних підставах постійно мешкає у відповідній державі упродовж п'яти років, що передують виборам [9].

Здійснюючи комплексний аналіз муніципально-правового статусу іноземців в Україні, А. Левенець акцентуе увагу на необхідності забезпечення можливостей для активної участі іноземців-постійних мешканців територіальної громади у вирішенні питань місцевого значення як важливої складової їх повноцінної інтеграції у місцеве співтовариство [10, с. 12]. Автор наводить перелік прав, якими володіють іноземцічлени територіальної громади в Україні на місцевому рівні, зокрема:

- право направляти індивідуальні чи колективні письмові звернення або особисто звертатися до органів місцевого самоврядування, їх посадових осіб;

- право на оскарження в суді рішень, дій чи бездіяльності органів місцевого самоврядування, а також на відшкодування за рахунок органів місцевого самоврядування матеріальної та моральної шкоди, завданої незаконними рішеннями, діями чи бездіяльністю органів місцевого самоврядування, їх посадових і службових осіб при здійсненні ними своїх повноважень;

- право брати участь у громадських слуханнях, право ініціювати розгляд у раді (в порядку місцевої ініціативи) будь-якого питання, віднесеного до відання місцевого самоврядування, право обирати та бути обраними до органу самоорганізації населення та ін.) [10, с. 14].

Отже, можемо констатувати факт, що іноземці в Україні позбавлені виборчих прав. Проте, попри існуючі недоліки чинного законодавства, в Україні унормована можливість залучення іноземців до участі у здійсненні місцевого самоврядування, що дозволяе посадовим особам місцевого самоврядування вивчати і враховувати позитивний зарубіжний досвід вирішення місцевих справ.

Російській збройній агресії проти України протистоять не лише українці, а й добровольці з інших країн. За різними даними, на сході України воюють громадяни Франції, Швеції, Німеччини, Італії, США, Грузії, Білорусі, країн Балтії, Фінляндії, Норвегії, Канади, Хорватії, Словенії, Чехії та навіть Росії.

У Законі України «Про внесення змін до деяких законодавчих актів України щодо проходження військової служби у Збройних Силах України іноземцями та особами без громадянства» передбачено, що іноземщі та особи без громадянства, які на законних підставах перебувають на території України, можуть у добро- вільному порядку (за контрактом) проходити військову службу у Збройних Силах України. [11].

Відповідні зміни було внесено до Кримінального кодексу України, а саме: статтею 447 «Найманство» визначаеться, що вербування, фрінансування, матеріальне забезпечення, навчання найманців 3 метою використання у збройних конфліктах, военних або насильницьких діях, а також використання найманців у збройних конфрліктах, военних або насильницьких діях - караються позбавленням волі на строк від п'яти до десяти років. Ті самі діяння, вчинені службовою особою 3 використанням службового становища, - караються позбавленням волі на строк від семи до дванадцяти років із конфіскаціею майна або без такої [12, с. 197-198].

Відповідно до примітки цієї статті, під найманцем розуміемо особу, яка: спеціально завербована в Україні чи за її межами для того, щоб брати на території України чи території інших держав участь у збройному конфлікті, военних або насильницьких діях, спрямованих на насильницьку зміну чи повалення конституційного ладу, захоплення державної влади, перешкоджання діяльності органів державної влади чи порушення територіальної цілісності; бере участь у военних або насильницьких діях з метою одержання будь-якої особистої вигоди; не $є$ ні громадянином (підданим) сторони, що перебувае у конфлікті, ні особою, яка постійно на законних підставах проживае на території, яка контролюється стороною, що перебуває у конфлікті; не входить до особового складу збройних сил держави, на території якої здійснюються такі дії; не послана державою, яка не є стороною, що перебуває у конфлікті, для виконання офіційних обов'язків як особи, яка входить до складу її збройних сил [12, c. 197-198].

Аналіз положень вищезгаданого Закону дозволяе стверджувати, що іноземщі та особи без громадянства, які проходять військову службу у Збройних Силах України прирівнюються до категорії військовослужбовців; іноземці можуть бути прийняті на військову службу до Збройних Сил України за контрактом на посади рядового, сержантського і старшинського складу. При цьому передбачено, що розмір грошового забезпечення іноземців, які проходять військову службу, визначається на рівні, що встановлений для військовослужбовців - громадян України, які проходять службу за контрактом. Одноразова допомога у разі загибелі (смерті), інвалідності або часткової втрати працездатності без встановлення інвалідності іноземців, які проходять військову службу у Збройних Силах України, - гарантована державою виплата, що здійснюеться особам, які згідно із Законом мають право на їі отримання [11].

Іноземці, які уклали контракт про проходження військової служби у Збройних Силах України, вважаються такими, які на законних підставах тимчасово проживають на території України на період дії контракту про проходження військової служби у Збройних Силах України.

Для іноземців, які в установленому законом порядку проходять військову службу за контрактом у Збройних Силах України, встановлено спрощений порядок прийняття до громадянства України. Відповідно до Закону України «Про 
громадянство України» на цю категорію осіб не поширюються такі умови прийняття до громадянства України, як: отримання дозволу на імміграцію; володіння державною мовою або її розуміння в обсязі, достатньому для спілкування; наявність законних джерел існування [13].

Для іноземців, які проходять військову службу за контрактом у Збройних Силах України, термін безперервного проживання на законних підставах на території України, що е необхідною умовою прийняття до громадянства, встановлюеться на три роки з моменту набрання чинності.

Отже, актуальним питанням на сьогодні $\epsilon$ належна правова регламентація процедури прийняття до громадянства України осіб, які захищали суверенітет, територіальну цілісність України та брали безпосередню участь в антитерористичній операції чи військових діях у складі добровольчих батальйонів, партизанських загонів, інших територіальних формувань, що співпрацювали зі Збройними Силами України, органами Міністерства внутрішніх справ України.

Висновки і пропозиції. У наш час кількість іноземних громадян, які перебувають на території України, постійно зростає. 3 цього випливає той вахт, що одним із головних пріоритетів України для зміцнення міжнародного суверенітету $є$ потреба вдосконалення вітчизняного законодавства щодо обсягу, змісту, механізмів реалізації та відповідності міжнародним стандартам основних прав і свобод такої категорії осіб, як іноземці, для визначення їх конституційно-правового статусу. Засади здійснення іноземцями своїх прав, свобод і обов'язків визначає правовий режим іноземців. В Україні стосовно іноземців діє національний режим, що передбачає зрівняння у правах і свободах іноземних громадян та громадян України, за винятками (йдеться передусім про політичні права), встановленими Конституціею, законами, міжнародними договорами України. Іноземці в Україні нарівні з громадяни України володіють певним обсягом конституційних обов'язків.

В умовах військової агресії до захисту суверенітету, територіальної цілісності України долучилися іноземні громадяни, увійшовши до складу добровольчих батальйонів та партизанських загонів. Багато з них прагнуть стати повноцінними громадянами України, а тому нагальним питанням нині є спрощення порядку прийняття таких осіб до громадянства України.

\section{Список літератури:}

1. Витрук Н. В. Общая теория правового положения личности : моноградрия. Москва : Норма, 2008. 448 с

2. Про правовий статус іноземців та осіб без громадянства : Закон України від 22 вересня 2011 p. № 3773-VI / Верховна Рада України. URL: https://zakon.rada.gov.ua/laws/show/3773-17\#Text (дата звернення: 10.11.2021).

3. Конституція України : Закон України від 28 червня 1996 р. № 254к/96-BP. URL: https://zakon.rada.gov.ua/ laws/show/254к/96-вр\#Text (дата звернення: 12.11.2021).

4. Петров Є. Ю. Конституційно-правовий статус іноземців в Україні та механізм його забезпечення : авторедр. дис. ... канд. юрид. наук : 12.00.02. Харків, 2013. 21 c. URL: https://mydisser.com/ru/catalog/view/15324.html

5. Про громадські об’еднання : Закон України від 22 березня 2012 р. № 4572-VI. URL: https://zakon.rada.gov.ua/ laws/show/4572-17\#Text (дата звернення: 13.11.2021).

6. Чернявський А. Л. Проблеми реалізації виборчих прав іноземців та осіб без громадянства в контексті евроінтеграції України. Вісник Університету банківської справи Національного банку України. 2014 . № 3. C. $25-27$.

7. Zákon zo 4. júla 2001 o volbách do orgánov samosprávnych krajov a o doplnení občianskeho súdneho poriadku. URL: https://www.noveaspi.sk/products/lawtext/1/51660/1/2 (дата звернення: 15.11.2021).

8. Грабильніков А. В. Конституційно-правовий статус і правовий режим іноземців та осіб без громадянства в Україні: співвідношення понять. Науковий збірник "Актуальні проблеми вітчизняної юриспруденцї̈». 2015. Випуск 6. С. 59-66.

9. Про участь іноземців у суспільному житті на місцевому рівні : Конвенція від 5 лютого 1992 р. / Верховна Рада України. URL: http://zakon4.rada.gov.ua/laws/show/994_318 (дата звернення: 16.11.2021).

10. Левенець А. В. Муніципально-правовий статус іноземців в Україні : автореф. дис. ... канд. юрид. наук : 12.00.02. Харків, 2017. 20 с.

11. Про внесення змін до деяких законодавчих актів України щодо проходження військової служби у Збройних Силах України іноземцями та особами без громадянства : Закон України від 6 жовтня 2015 р. № 716-VIII / Верховна Рада України. URL: http://zakon.rada.gov.ua/laws/show/716-19 (дата звернення: 18.11.2021).

12. Кримінальний кодекс України. С. : ТОВ «ВВП НОТІС», 2017. 204 с.

13. Про громадянство України : Закон України від 18 січня 2001 р. № 2235-III / Верховна Рада України. URL: http://zakon.rada.gov.ua/laws/show/2235-14/ed20160219 (дата звернення: 20.11.2021).

\section{References:}

1. Vitruk, N. V. (2008) Obshchaia teoryia pravovoho polozhenyia lychnosty [General theory of the legal status of the individual]: monograph. Moscow: Norma, $448 \mathrm{p}$.

2. Pro pravovyi status inozemtsiv ta osib bez hromadianstva [About the Legal Status of Foreign citizens and Stateless Persons]. Available at: https://zakon.rada.gov.ua/laws/show/3773-17\#Text (accessed 5 November 2021).

3. Konstytutsiia Ukrainy [Constitution of Ukraine]: Law of Ukraine of June 28, 1996, No. 254k/96-VR / Verkhovna Rada of Ukraine. Vedomosti Verkhovnaia Rada of Ukraine. 1996. № 30.

4. Petrov, Y. (2013) Konstytutsiino-pravovyi status inozemtsiv v Ukraini ta mekhanizm yoho zabezpechennia [The constitutional and legal status of foreigners in Ukraine and the mechanism of its security]: avtoref. dys. ... kand. yuryd. nauk: 12.00.02. Kharkiv, $21 \mathrm{p}$.

5. Pro hromadski obiednannia [About community associations]. Available at: https://zakon.rada.gov.ua/laws/ show/4572-17\#Text (accessed 13 November 2021).

6. Cherniavskyi, A. L. (2014) Problemy realizatsii vyborchykh prav inozemtsiv ta osib bez hromadianstva v konteksti yevrointehratsii Ukrainy [Problems of Realization of Electoral Rights of Foreigners and Stateless Persons in the Context of European Integration of Ukraine]. Visnyk Universytetu bankivskoi spravy Natsionalnoho banku Ukrainy, no. 3, pp. 25-27. 
7. Zákon zo 4. júla 2001 o volbách do orgánov samosprávnych krajov a o doplnení občianskeho súdneho poriadku. Available at: https://www.noveaspi.sk/products/lawtext/1/51660/1/2 (accessed 13 November 2021).

8. Grabilnikov, A. V. (2015) Konstytutsiino-pravovyi status i pravovyi rezhym inozemtsiv ta osib bez hromadianstva v Ukraini: spivvidnoshennia poniat [Constitutional and legal status and legal regime of foreigners and stateless persons in Ukraine: comparisons understood]. Naukovyi zbirnyk "Aktualni problemy vitchyznianoi yurysprudentsii», vol. 6, pp. 59-66.

9. Pro uchast inozemtsiv u suspilnomu zhytti na mistsevomu rivni [On the Participation of Foreigners in Public Life at the Local Level]. Available at: http://zakon4.rada.gov.ua/laws/show/994_318 (accessed 16 November 2021).

10. Levenets, A. V. (2017) Munitsypalno-pravovyi status inozemtsiv v Ukraini [Munitsipal-legal status of foreigners in Ukraine]: avtoref. dys. ... kand. yuryd. nauk: 12.00.02. Kharkiv, $20 \mathrm{p}$.

11. Pro vnesennia zmin do deiakykh zakonodavchykh aktiv Ukrainy shchodo prokhodzhennia viiskovoi sluzhby u Zbroinykh Sylakh Ukrainy inozemtsiamy ta osobamy bez hromadianstva [On making amendments to some legislative acts of Ukraine on military service in the Armed Forces of Ukraine by foreigners and persons without citizenship]. Available at: http://zakon.rada.gov.ua/laws/show/716-19 (accessed 18 November 2021).

12. Kryminalnyi kodeks Ukrainy [Criminal Code of Ukraine] (2017). S.: TOV «VVP NOTIS», 204 p.

13. Pro hromadianstvo Ukrainy [About Ukraine's citizenship]. Available at: http://zakon.rada.gov.ua/laws/show/ 2235-14/ed20160219 (accessed 20 November 2021). 